\title{
An overlooked fact: thrombocytopenia following bioprosthetic aortic valve replacement
}

\author{
Mehmet Kizilay, Ferruh Elbir, Ahmet Arif Aglar, Unsal Vural, Ahmet Yavuz Balci, İbrahim Yekeler \\ Department of Cardiovascular Clinic, Dr Siyami Ersek Hast, Istanbul, Turkey
}

Kardiochirurgia i Torakochirurgia Polska 2019; 16 (1): 19-26

\begin{abstract}
Introduction: Thrombocytopenia observed after bioprosthetic aortic valve replacement has remained a puzzle to solve.

Aim: To analyze thrombocytopenia occurring after bioprosthetic aortic valve replacement by comparison to mechanical aortic valve replacement and coronary artery bypass grafting procedures.

Material and methods: The study was conducted retrospectively on a total of 297 patients who underwent bioprosthetic aortic valve replacement, mechanical prosthetic aortic valve replacement and coronary artery bypass grafting at the cardiovascular surgery department of our clinical center between January 2013 and September 2017. Preoperative and postoperative first 14-day thrombocyte levels of the patients were analyzed.

Results: The postoperative blood thrombocyte level decrease was found to be more significant in patients who underwent bioprosthetic aortic valve replacement than in patients who underwent mechanical aortic valve replacement and coronary artery bypass grafting $(p<0.01)$. There was also a statistically significant difference in the time to reach the lowest postoperative platelet levels according to type of surgery ( $p=0.001$; $p<0.01$ )

Conclusions: When compared to the patients who underwent coronary artery bypass grafting and mechanical prosthetic aortic valve replacement, postoperative thrombocytopenia was found to be more severe in patients who underwent bioprosthetic aortic valve replacement, with a dramatic decrease in thrombocyte count being observed on the postoperative second day. It was found that the thrombocytopenia recovers without causing any problem. We think that the shear forces may play a role in this recovery through washout of chemicals responsible for thrombocytopenia from the glutaraldehyde treated bioprostheses.
\end{abstract}

Key words: platelet levels, bleeding complication, bioprosthetic aortic valve replacement.

\section{Streszczenie}

Wprowadzenie: Trombocytopenia stwierdzana po wymianie bioprotezy zastawki aortalnej pozostaje zagadką, która wymaga rozwiązania.

Cel: Analiza trombocytopenii występującej po wymianie bioprotezy zastawki aortalnej w porównaniu z trombocytopenią po wymianie mechanicznej zastawki aortalnej i pomostowaniu aortalno-wieńcowym.

Materiat i metody: Retrospektywnym badaniem objęto łącznie 297 pacjentów, u których przeprowadzono wymianę bioprotezy zastawki aortalnej, wymianę mechanicznej zastawki aortalnej i pomostowanie aortalno-wieńcowe na oddziale kardiochirurgii w ośrodku autorów od stycznia 2013 do września 2017 r. Analizowano poziom płytek krwi przed operacją i w ciągu pierwszych 14 dni po zabiegu.

Wyniki: Stwierdzono większe pooperacyjne zmniejszenie poziomu płytek krwi u pacjentów po wymianie bioprotezy zastawki aortalnej niż u pacjentów po wymianie mechanicznej zastawki aortalnej i po pomostowaniu aortalno-wieńcowym ( $p<0,01)$. Wykazano również statystycznie istotną różnicę w zakresie czasu koniecznego do osiągnięcia najniższego poziomu płytek krwi po operacji w zależności od rodzaju zabiegu $(p=0,001 ; p<0,01)$.

Wnioski: W porównaniu z pacjentami, u których przeprowadzono pomostowanie aortalno-wieńcowe i wymianę mechanicznej zastawki aortalnej, poważniejszą pooperacyjną małopłytkowość stwierdzono u pacjentów, którzy przeszli wymianę bioprotezy zastawki aortalnej, przy czym gwałtowne zmniejszenie liczby płytek krwi zaobserwowano w drugim dniu po operacji. Trombocytopenia ustępuje, nie powodując żadnych problemów. Naszym zdaniem w tym przypadku ważną rolę odgrywają siły ścinające poprzez eliminację lub wymywanie substancji chemicznych odpowiadających za trombocytopenię spowodowaną przez bioprotezy poddane działaniu aldehydu glutarowego.

Słowa kluczowe: poziom płytek krwi, powikłania w zakresie krwawienia, wymiana bioprotezy zastawki aortalnej.

Address for correspondence: Mehmet Kizilay PhD, Department of Cardiovascular Clinic, Dr Siyami Ersek Hast, Tıbbiye C No. 30,

34692 Istanbul, Turkey, phone: +90 5334218433, e-mail: kzlay@yahoo.com

Received: 24.10.2018, accepted: 27.12.2018. 


\section{Introduction}

Surgery is a frequent cause of secondary thrombocytopenia [1]. In cardiac surgery, hemodilutional and the destructive effect of the cardiopulmonary bypass circuit on thrombocyte count could lead to more than a 50\% decrease in platelet count compared to pre-cardiopulmonary bypass values [2]. Typically, the lowest platelet count is found to be $40 \%$ to $60 \%$ of the preoperative blood thrombocyte level and is detected on the postoperative second or third day [3]. In $10 \%$ of patients, more than a $50 \%$ reduction in thrombocyte count in comparison to preoperative levels is observed on the fourth postoperative day [4]. Furthermore, preoperative use of antiplatelet agents, prolonged cardiopulmonary bypass (CPB) time, and hypothermia aggravate thrombocyte dysfunction. Plasmin also contributes to platelet dysfunction. On the other hand, persistent bleeding can add to coagulation dysfunction by exhausting coagulation factors and platelets [5, 6]. In conclusion, cardiac surgery is a process prolonging the postoperative bleeding time by affecting platelets both quantitatively and qualitatively. Regarding aortic valve surgery, valve replacement is the most commonly used procedure despite the presence of multiple aortic valve repair procedures. The prostheses used in heart valve replacement are grouped into two main types, mechanical and bioprosthesis. Today, in spite of technological and surgical developments, the rate of such complications related to prosthetic valves as bleeding, systemic embolization, valve thrombosis, infection, hemolysis and anticoagulation has decreased but the ideal valve has not been obtained yet. Long-term durability of the mechanical prosthesis is a significant advantage over the bioprosthesis. However, the necessity of lifelong warfarin use in this valve group is disadvantageous compared to the bioprosthesis valve group. On the other hand, common problems of bioprosthetic valves are early degeneration and infection [7]. The use of bioprosthetic valves is always a priority in elderly patients due to the low expectation of life, and the increased risk of hemorrhage or thrombosis due to impaired awareness of warfarin use [8-10].

Aortic valve surgery is a complicated procedure and multidisciplinary follow-up should be performed preoperatively, peroperatively and postoperatively. As in other fields of surgery, the problem of bleeding is the most important factor in increasing mortality and morbidity in aortic valve surgery. The most important parameter for the bleeding and coagulation system is the amount of platelets and their functions. Since platelet activation is known to be a side effect of the cardiac surgery, a number of analyses have been performed to identify the relationship between postoperative thrombocytopenia and aortic valve replacement (AVR). Thrombocytopenia must have a platelet count below $50,000 / \mathrm{mm}^{3}$ in order to cause serious bleeding complications [11]. After a usual procedure employing cardiopulmonary bypass, the thrombocyte count remains over $100,000 / \mathrm{mm}^{3}$ despite a reduction of $30 \%$ to $50 \%$. Although the bleeding time nearly doubles after CPB, it returns to a normal level within 4 to 12 hours.

Thrombocytopenia developed in the postoperative period after biological aortic valve replacement is observed to have a significantly different pattern and intensity compared to the one seen after CABG and mechanical AVR operations performed under cardiopulmonary bypass.

\section{Aim}

In this study, we aimed to investigate the causes of thrombocytopenia after biological AVR and to investigate whether thrombocytopenia is an additional effect in increasing postoperative bleeding or complications.

\section{Material and methods Patients}

We retrospectively evaluated 297 patients who underwent biological AVR, CABG and mechanical AVR between January 2013 and September 2017 in our clinic. In the study, bioprosthetic AVR patients, mechanical prosthetic AVR patients, and CABG patients were defined as group 1 , group 2, and group 3, respectively. Patients who underwent double-valve surgery or reoperation, and those with active endocarditis, were excluded from the study. Preoperative and postoperative first 14-day thrombocyte levels of the patients were analyzed. Additionally, patients were analyzed with respect to postoperative bleeding complications and need for renal replacement therapy. Information regarding the gender, age, and thrombocyte count of patients, type of operation done, type and size of prosthesis used, postoperative intra-aortic balloon pump and hemodialysis requirement, and postoperative bleeding complication that required intervention was determined and listed. Daily thrombocyte levels of the patients in whom on at least one of the postoperative first three days the platelet counts were 70 and below were recorded. Patients were classified as having a thrombocyte level of 1-49 $\left(1000 / \mathrm{mm}^{3}\right), 50-149\left(1000 / \mathrm{mm}^{3}\right)$, and $150\left(1000 / \mathrm{mm}^{3}\right)$ or more in terms of platelet counts (Tables I-III). The Sorin

Table I. Distribution of descriptive properties

\begin{tabular}{llcrr} 
Parameter & & \multicolumn{1}{c}{ Total } & \multicolumn{2}{c}{ Type of surgery } \\
\cline { 3 - 5 } & & & $\begin{array}{c}\text { Bioprosthetic AVR } \\
(n=97)\end{array}$ & $\begin{array}{c}\text { Mechanical prosthetic AVR } \\
(n=100)\end{array}$ \\
Age [years] & Min.-max. (median) & $17-88(65)$ & $23-88(73)$ & $17-80(59)$ \\
\cline { 2 - 5 } & Mean \pm SD & $63.11 \pm 13.33$ & $72.56 \pm 10.14$ & $55.46 \pm 14.73$ \\
\hline Gender, $n(\%)$ & Female & $84(28.3)$ & $40(41.2)$ & $27(27.0)$ \\
\cline { 2 - 5 } & Male & $213(71.7)$ & $57(58.8)$ & $73(73.0)$ \\
\hline
\end{tabular}


Mitroflow aortic pericardial heart valve was preferred as a bioprosthetic valve while the Sorin Carbomedics bileaflet aortic prosthetic heart valve was preferred as a mechanical prosthesis.

\section{Surgical technique}

Under general anesthesia, following median sternotomy, cardiopulmonary bypass was instituted with moderate hypothermia $\left(32-34^{\circ} \mathrm{C}\right)$. During AVR operations, the aorta was partially transected and the cardioplegia delivery was done directly through the coronary ostia and repeated at 20 minutes intervals. Aortic valve leaflets and calcifications were removed. Biological prostheses were washed for a sufficient period of time until the glutaraldehyde was thought to be completely cleared. In accordance with the manufacturer's recommendations valves were rinsed with normal saline at $18-20^{\circ} \mathrm{C}$ for 3 minutes before implantation and then the prosthesis was implanted. In patients who underwent coronary artery bypass grafting, the left internal mammary artery was preferred for the revascularization of the left anterior descending artery while the great saphenous vein was used in revascularization of other coronary arteries. In coronary artery bypass grafting (CABG), distal anastomoses were performed under the cross clamp, and proximal anastomoses under the side clamp. Patients were taken to the intensive care unit after the operation.

\section{Anticoagulation protocol}

In patients who underwent coronary artery bypass surgery, medical treatment of acetylsalicylic acid (300 mg/day p.o.) and enoxaparin $(2 \times 1 \mathrm{mg} / \mathrm{kg} /$ day s.c.) was started on the postoperative first day. All patients who underwent valve surgery were put under enoxaparin $(2 \times 1 \mathrm{mg} / \mathrm{kg} /$ day s.c.) therapy starting from the postoperative first day with warfarin being added on the postoperative second day. On the following days, the warfarin dose was adjusted so that the INR value would be $2-2.5$ times the normal. In patients with a bioprosthetic valve use of warfarin was discontinued at the $6^{\text {th }}$ month of follow-up unless there was atrial fibrillation and acetylsalicylic acid (100 mg/day p.o.) therapy was started. Patients with mechanical prostheses were put under lifelong warfarin therapy with INR controls at certain intervals.
Table II. Distributions of PLT measurements

\begin{tabular}{lccc} 
PLT & $N$ & $\begin{array}{c}\text { Min.-max. } \\
\text { (median) }\end{array}$ & Mean \pm SD \\
Preop. day & 297 & $91-470(219)$ & $226.74 \pm 58.08$ \\
\hline Operation moment & 292 & $53-417(146.5)$ & $151.34 \pm 52.27$ \\
\hline Day 1 & 294 & $32-365(139.5)$ & $140.76 \pm 52.29$ \\
\hline Day 2 & 289 & $14-328(132)$ & $133.68 \pm 56.57$ \\
\hline Day 3 & 181 & $31-338(125)$ & $127.97 \pm 58.23$ \\
\hline Day 4 & 168 & $31-501(156)$ & $162.86 \pm 75.76$ \\
\hline Day 5 & 171 & $18-531(190)$ & $193.51 \pm 89.60$ \\
\hline Day 6 & 135 & $10-564(210)$ & $209.37 \pm 100.76$ \\
\hline Day 7 & 162 & $24-702(261.5)$ & $259.47 \pm 123.33$ \\
\hline Day 14 & 276 & $76-813(403.5)$ & $393.66 \pm 145.52$ \\
\hline Day 30 & 217 & $80-661(282)$ & $290.76 \pm 102.55$ \\
\hline
\end{tabular}

\section{Statistical analysis}

The NCSS (Number Cruncher Statistical System) 2007 (Kaysville, Utah, USA) program was used for statistical analysis. Student's $t$ test was used for two-group comparisons of normal distributions in the comparison of quantitative data, and the Mann-Whitney $U$ test was used for two-group comparisons of non-normal distributions beside the descriptive statistical methods (mean, standard deviation, median, frequency, rate, minimum, and maximum). One-way ANOVA test was used for the comparison of three groups with normal distribution, and the Kruskal-Wallis test was used for three groups with non-normal distribution. Age, gender and group effects on platelet values $<150$ $\left(1000 / \mathrm{mm}^{3}\right)$ were examined by enter logistic regression analysis. Pearson correlation analysis and Spearman's correlation analysis were used in evaluating inter-variable relationships. Pearson $\chi^{2}$ test, Fisher-Freeman-Halton test and Fisher's exact test were used for comparison of qualitative data. The effects of risk factors on platelet values below $150\left(1000 / \mathrm{mm}^{3}\right)$ were assessed by multivariate logistic regression analysis. The significance level was $p<0.05$.

\section{Results}

Of the cases, $28.3 \%(n=84)$ were female and $71.7 \%$ were male $(n=213)$. The ages of the patients ranged from 17 to 88 years with a mean age of $63.11 \pm 13.33$ years (Table I).

Table III. Distribution of IABP requirement, hemodialysis requirement and postoperative intervention due to bleeding according to type of surgery

\begin{tabular}{|c|c|c|c|c|c|}
\hline \multirow[t]{2}{*}{ Parameter } & & \multirow[t]{2}{*}{ Total } & \multicolumn{3}{|c|}{ Type of surgery } \\
\hline & & & $\begin{array}{l}\text { Bioprosthetic AVR } \\
\quad(n=97)\end{array}$ & $\begin{array}{l}\text { Mechanical prosthetic AVR } \\
\qquad(n=100)\end{array}$ & $\begin{array}{c}\text { CABG } \\
(n=100)\end{array}$ \\
\hline \multirow[t]{2}{*}{ IABP requirement $(n=292)$} & No & $288(98.6)$ & $94(98.9)$ & $99(99.0)$ & $95(97.9)$ \\
\hline & Yes & $4(1.4)$ & $1(1.1)$ & $1(1.0)$ & $2(2.1)$ \\
\hline \multirow[t]{2}{*}{ Hemodialysis requirement $(n=272)$} & No & $269(98.9)$ & $94(98.1)$ & $99(99.0)$ & $76(98.7)$ \\
\hline & Yes & $3(1.1)$ & $1(1.1)$ & $1(1.0)$ & $1(1.3)$ \\
\hline \multirow[t]{2}{*}{ Postoperative intervention due to bleeding $(n=292)$} & No & $261(89.4)$ & $88(92.6)$ & $92(92.0)$ & $81(83.5)$ \\
\hline & Yes & 31 (10.6) & $7(7.4)$ & $8(8.0)$ & $16(16.5)$ \\
\hline
\end{tabular}


The lowest postoperative platelet measurements obtained at follow-ups ranged from 10 to $320\left(1000 / \mathrm{mm}^{3}\right)$, with a mean of $118.02 \pm 49.23\left(1000 / \mathrm{mm}^{3}\right)$. The time to reach the lowest postoperative platelet measurement ranged from 0 to 14 days with an average of $1.70 \pm 1.65$ days.

Thrombocytopenia was observed in $96.9 \%$ of patients who underwent bioprosthetic AVR. This percentage was $72 \%$ in patients with mechanical prosthetic AVR patients. The incidence of thrombocytopenia in the bioprosthetic AVR group was significantly higher than the mechanical prosthetic AVR $(p=0.001)$ and CABG $(p=0.001)$ groups $(p<0.01)$. Severe thrombocytopenia $\left(0-50 \times 10^{3} / \mathrm{mm}^{3}\right)$ was observed in $21.6 \%$ of patients using a bioprosthesis. However, severe thrombocytopenia was not observed in patients who underwent mechanical prosthetic AVR and CABG. Patients who underwent bioprosthetic AVR had the lowest platelet counts after an average of 2 days. In comparison of the difference between the preoperative and the lowest postoperative platelet values, the difference observed in the bioprosthetic AVR group was found to be significantly larger than that in the mechanical prosthetic AVR group $(p=0.001)$ and CABG group $(p=0.001)(p<0.01)$.

The lowest postoperative platelet measurements according to the type of surgery showed a statistically significant difference ( $p=0.001, p<0.01)$. As a result of the binary comparisons to determine which group the significance originates from, the measurements of the bioprosthetic AVR group were found to be significantly lower than those of the mechanical prosthetic AVR group $(p=0.001)$ and CABG group $(p=0.001)$. The lowest postoperative platelet measurements of the mechanical prosthetic AVR group were statistically significantly lower than those of the CABG group ( $p=0.040, p<0.05)$.

The rate of platelet measurements in the range of $1-49\left(1000 / \mathrm{mm}^{3}\right)$ in the bioprosthetic AVR group was significantly higher than the mechanical prosthetic AVR and CABG groups ( $p=0.001 ; p<0.01)$. Similarly, the incidence of falling of platelet levels below $150\left(1000 / \mathrm{mm}^{3}\right)$ at any given time shows a statistically significant difference according to the type of operation ( $p=0.001, p<0.01$ ). Binary comparisons to determine which group the significance originates from revealed that the proportion of platelet measurements below $150\left(1000 / \mathrm{mm}^{3}\right)$ in the biological valve group was significantly higher than that in the mechanical prosthetic AVR group ( $p=0.001)$ and CABG group $(p=0.001)$. In this respect, no statistically significant difference was found between the mechanical prosthetic AVR group and CABG group $(p>0.05)$.

Statistically significant differences were found between platelet levels according to the type of operation $(p=0.001$; $p<0.01)$. In the bioprosthetic AVR group, the percentage of the platelet counts in the range of $1-49\left(1000 / \mathrm{mm}^{3}\right)$ was significantly higher than in the mechanical prosthetic AVR and CABG groups ( $p=0.001, p<0.01)$. The percentage of the platelet counts in the range of $50-99\left(1000 / \mathrm{mm}^{3}\right)$ in the bioprosthetic AVR group was significantly higher than those in the mechanical prosthetic AVR and CABG groups.
In the mechanical prosthetic AVR group, the percentage of the platelet counts in the range of $50-99\left(1000 / \mathrm{mm}^{3}\right)$ was significantly higher than in the CABG group $(p=0.001$, $p<0.01)$. The percentage of the platelet counts in the range of 100-149 $\left(1000 / \mathrm{mm}^{3}\right)$ in the bioprosthetic AVR group was significantly lower than those in the mechanical prosthetic AVR and CABG groups ( $p=0.001, p<0.01)$. In the bioprosthetic AVR group, the percentage of the platelet measurements over $150\left(1000 / \mathrm{mm}^{3}\right)$ was significantly lower than in the mechanical prosthesis AVR and CABG groups $(p=0.001, p<0.01)$.

The differences between the preoperative platelet measurements and the lowest postoperative platelet measurements were statistically significant with regard to type of surgery $(p=0.001 ; p<0.01)$. Binary comparisons to determine which group the significance originates from revealed that the differences in the bioprosthetic AVR group were significantly larger than those of the mechanical prosthetic $\operatorname{AVR}(p=0.001)$ and CABG $(p=0.001)$ groups $(p<0.01)$. In this respect, there was no statistically significant difference between mechanical prosthetic AVR and CABG groups $(p>0.05)$. Average prosthesis size of the patients whose platelet measurements at any time were found to be below $150\left(1000 / \mathrm{mm}^{3}\right)$ was $22.11 \pm 1.33 \mathrm{~mm}$, whereas that of the cases having a platelet count of $150\left(10000 / \mathrm{mm}^{3}\right)$ or more was $22.33 \pm 2.31 \mathrm{~mm}$ (Table IV).

The rate of the platelet level being lower than 150 $\left(1000 / \mathrm{mm}^{3}\right)$ at least once in any measurement was found to be $76.1 \%(n=226)$, while the rate of the platelet level being 150 $\left(1000 / \mathrm{mm}^{3}\right)$ or more was $23.9 \%(n=71)$. Platelet levels ranged from 1 to $49\left(1000 / \mathrm{mm}^{3}\right)$ in $7.1 \%$ of cases $(n=21)$; between 50 and $99\left(1000 / \mathrm{mm}^{3}\right)$ in 30.0\% $(n=89)$; between 100 and $149\left(1000 / \mathrm{mm}^{3}\right)$ in 39.1\% $(n=116)$; and $150\left(1000 / \mathrm{mm}^{3}\right)$ or more in $23.9 \%(n=71)$. The differences between the preoperative and the postoperative lowest platelet (PLT) measurements ranged from 2 to $385\left(1000 / \mathrm{mm}^{3}\right)$ with a mean of $108.71 \pm 56.37\left(1000 / \mathrm{mm}^{3}\right)$ (Table V).

There was no statistically significant difference between thrombocyte levels with regard to the sizes of bioprosthetic valves used $(p>0.05)$ (Table VI).

There was no statistically significant difference in terms of intervention due to bleeding, intra-aortic balloon pump (IABP) or hemodialysis requirement in the three groups (Table III).

In all of the women $100 \%(n=40)$ and $94.7 \%$ of the males $(n=54)$ platelet levels were found to be below $150\left(1000 / \mathrm{mm}^{3}\right)$ at least once in any measurement. Platelet levels falling below $150(1000 / \mathrm{mmt})$ did not show a statistically significant difference according to gender. There was no significant difference in age and gender in the mechanical AVR and CABG groups ( $p>0.05$ ) (Table VII).

Among the risk factors thought to affect platelet levels falling below $150\left(1000 / \mathrm{mm}^{3}\right)$, age, gender and the type of surgery were found to be statistically significant when evaluated by enter logistic regression analysis $(p<0.01)$. In the model, the effect of bioprosthetic valve use was found significant $(p<0.01)$. The odds ratio of bioprosthetic valve 
Table IV. Evaluation of platelet measurements according to type of surgery

\begin{tabular}{|c|c|c|c|c|c|}
\hline \multirow[t]{2}{*}{ Parameter } & & \multicolumn{3}{|c|}{ Type of surgery } & \multirow[t]{2}{*}{$P$-value } \\
\hline & & $\begin{array}{l}\text { Bioprosthetic AVR } \\
(n=97)\end{array}$ & $\begin{array}{l}\text { Mechanical prosthetic AVR } \\
\qquad(n=100)\end{array}$ & $\begin{array}{c}\text { CABG } \\
(n=100)\end{array}$ & \\
\hline \multirow{2}{*}{$\begin{array}{l}\text { Minimum platelet count } \\
{\left[\times 10^{3} / \mathrm{mm}^{3}\right]}\end{array}$} & Min.-max. (median) & 10-182 (72) & $55-320(130)$ & $77-283$ (141.5) & \multirow[t]{2}{*}{${ }^{\mathrm{a}} 0.001^{\star \star}$} \\
\hline & Mean \pm SD & $76.99 \pm 35.02$ & $130.93 \pm 43.53$ & $144.92 \pm 40.16$ & \\
\hline \multirow{2}{*}{$\begin{array}{l}\text { Time to reach the lowest } \\
\text { postoperative platelet count } \\
\text { [days] }\end{array}$} & Min.-max. (median) & $0-14(2)$ & $0-4(1)$ & 0-14 (1) & \multirow[t]{2}{*}{$\mathrm{b}_{0} 0.001^{\star \star}$} \\
\hline & Mean \pm SD & $2.37 \pm 1.79$ & $1.41 \pm 1.12$ & $1.35 \pm 1.77$ & \\
\hline \multirow[t]{6}{*}{ Platelet levels, $n(\%)$} & $<150$ & 94 (96.9) & $72(72.0)$ & $60(60.0)$ & \multirow[t]{2}{*}{${ }^{c} 0.001^{\star *}$} \\
\hline & $\geq 150$ & $3(3.1)$ & $28(28.0)$ & $40(40.0)$ & \\
\hline & $1-49$ & $21(21.6)$ & $0(0)$ & $0(0)$ & ${ }^{c} 0.001^{* *}$ \\
\hline & $50-99$ & $51(52.6)$ & $25(25.0)$ & $13(13.0)$ & ${ }^{c} 0.001^{\star *}$ \\
\hline & $100-149$ & $22(22.7)$ & $47(47.0)$ & $47(47.0)$ & ${ }^{c} 0.001^{\star *}$ \\
\hline & $\geq 150$ & $3(3.1)$ & $28(28.0)$ & $40(40.0)$ & ${ }^{c} 0.001^{* *}$ \\
\hline \multirow{2}{*}{$\begin{array}{l}\text { Difference between } \\
\text { the preoperative and } \\
\text { the lowest postoperative } \\
\text { platelet counts }\left[\times 10^{3} / \mathrm{mm}^{3} \text { ] }\right.\end{array}$} & Min.-max. (median) & 21-385 (139) & $7-248(91)$ & $2-222(85)$ & \multirow[t]{2}{*}{$\mathrm{b}_{0} 0.001^{\star *}$} \\
\hline & Mean \pm SD & $146.08 \pm 58.12$ & $95.61 \pm 45.62$ & $85.57 \pm 45.42$ & \\
\hline
\end{tabular}

aOne-way ANOVA test, ${ }^{b}$ Kruskal-Wallis test, ${ }^{\text {CPearson }} \chi^{2}$ test, ${ }^{* *} p<0.01$.

Table V. Distributions related to platelet measurements

\begin{tabular}{|c|c|c|}
\hline Parameter & & Value \\
\hline \multirow{2}{*}{$\begin{array}{l}\text { Minimum platelet } \\
\text { count }\left[\times 10^{3} / \mathrm{mm}^{3}\right]\end{array}$} & Min.-max. (median) & $10-320(116)$ \\
\hline & Mean \pm SD & $118.02 \pm 49.23$ \\
\hline \multirow{2}{*}{$\begin{array}{l}\text { Time to reach the } \\
\text { lowest postoperative } \\
\text { platelet count [days] }\end{array}$} & Min.-max. (median) & $0-14(2)$ \\
\hline & Mean \pm SD & $1.70 \pm 1.65$ \\
\hline \multirow[t]{6}{*}{ Platelet levels, $n$ (\%) } & $<150$ & $226(76.1)$ \\
\hline & $\geq 150$ & $71(23.9)$ \\
\hline & $1-49$ & $21(7.1)$ \\
\hline & 50-99 & $89(30.0)$ \\
\hline & 100-149 & $116(39.1)$ \\
\hline & $\geq 150$ & $71(23.9)$ \\
\hline \multirow{2}{*}{$\begin{array}{l}\text { Difference between } \\
\text { the preoperative } \\
\text { and the lowest } \\
\text { postoperative platelet } \\
\text { counts }\left[\times 10^{3} / \mathrm{mm}^{3}\right]\end{array}$} & Min.-max. (median) & 2-385 (103) \\
\hline & Mean \pm SD & $108.71 \pm 56.37$ \\
\hline
\end{tabular}

use was found to be 16.779 (95\% Cl: 4.816-58.548), which means that bioprosthetic valve use has a 16.779 times more impact on causing platelet levels to fall below 150 $\left(1000 / \mathrm{mm}^{3}\right)$ when compared to CABG. The effect of mechanical prosthesis use was also very close to the level of significance and the odds ratio was found to be 1.842 (95\% Cl: 0.985-3.442). Age and gender effects were not significant $(p>0.05)$ (Table VIII).

\section{Discussion}

Among the possible causes of thrombocytopenia following bioprosthetic AVR, the effect of CPB is undeniable. It is known that CPB affects both platelet count and function adversely. Studies have shown that the platelet count
Table VI. Assessment of platelet levels according to prosthesis sizes in bioprosthetic AVR group $(n=97)$

\begin{tabular}{|c|c|c|c|c|}
\hline \multirow{2}{*}{$\begin{array}{l}\text { Platelet } \\
\text { levels }\end{array}$} & \multirow[t]{2}{*}{$N$} & \multicolumn{2}{|l|}{ Size } & \multirow[t]{2}{*}{ P-value } \\
\hline & & Min.-max. (median) & Mean \pm SD & \\
\hline$<150$ & 94 & $19-27(23)$ & $22.11 \pm 1.33$ & \multirow[t]{2}{*}{-} \\
\hline$\geq 150$ & 3 & $21-25(21)$ & $22.33 \pm 2.31$ & \\
\hline $1-49$ & 21 & $21-25(23)$ & $22.24 \pm 1.18$ & \multirow[t]{4}{*}{${ }^{\mathrm{a}} 0.610$} \\
\hline 50-99 & 51 & $19-25(21)$ & $21.98 \pm 1.29$ & \\
\hline $100-149$ & 22 & $21-27(22)$ & $22.27 \pm 1.58$ & \\
\hline$\geq 150$ & 3 & $21-25(21)$ & $22.33 \pm 2.31$ & \\
\hline
\end{tabular}

The group in which the platelet count was $\geq 150\left(1000 / \mathrm{mm}^{3}\right)$ has not been included in the evaluation because the number of people belonging to the group was insufficient. a One-way ANOVA test.

decreases rapidly to $50 \%$ of the preoperative levels shortly after CPB has been instituted [12].

A study by Hilker et al. reported that the time for postoperative thrombocyte counts to return to preoperative levels differed with regard to the type of implanted aortic valve prosthesis. This suggests that the material used during the construction of different prosthetic valves is responsible. Although these observations supported the association between platelet activation and bioprosthesis variants, the cause-and-effect relationship was not clearly established [13].

A study of the relationship between valve prosthesis types and thrombocytopenia by Ravenni et al. revealed a decrease in platelet counts in all bioprosthesis types on postoperative day 1. In comparison with Medtronic Mosaic (MOS) and Sorin Mitroflow (MIT) valves, the significant decrease in thrombocyte counts continued through the postoperative $3^{\text {rd }}$ to $5^{\text {th }}$ days in patients with a Sorin Freedom Solo (SFS) prosthesis [14]. 


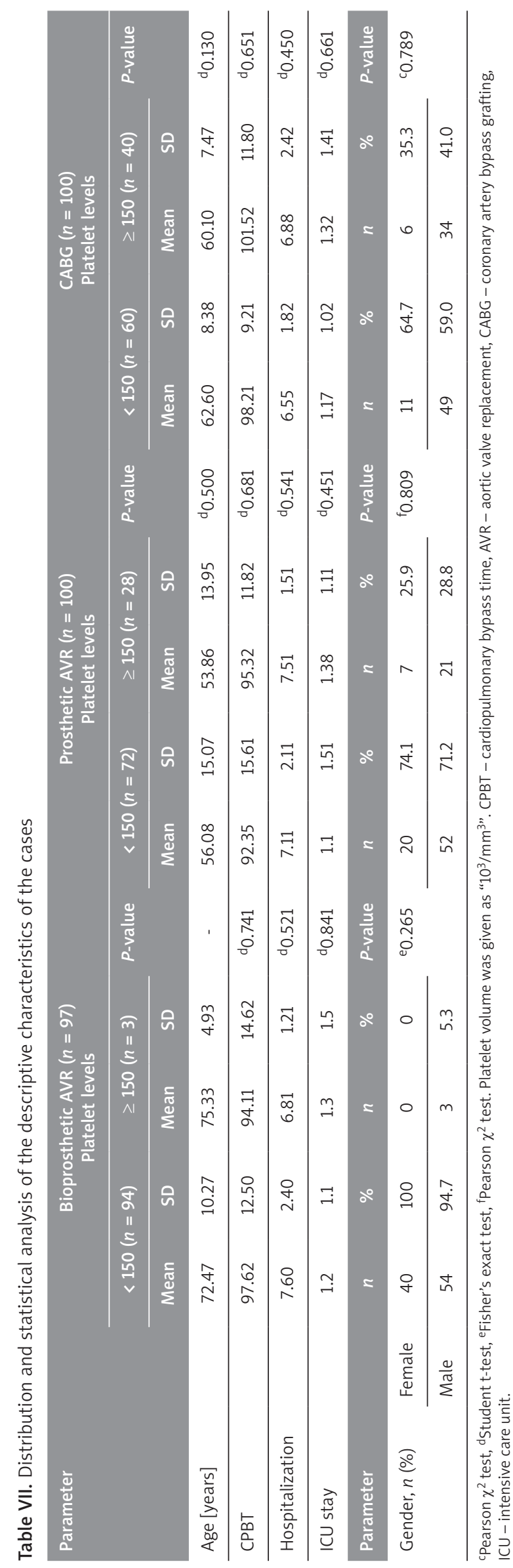

Table VIII. Logistic regression analysis of risk factors affecting platelet levels $<150\left(1000 / \mathrm{mm}^{3}\right)$

\begin{tabular}{lcccc} 
Parameter & P-value & Odds & \multicolumn{2}{c}{$95 \% \mathrm{Cl}$} \\
\cline { 4 - 5 } & & & Lower & Upper \\
Age & 0.243 & 1.015 & 0.990 & 1.040 \\
\hline Gender (female) & 0.401 & 1.361 & 0.663 & 2.792 \\
\hline Method & $0.001^{\star \star}$ & & & \\
\hline Method (bioprosthetic AVR) & $0.001^{\star *}$ & 16.779 & 4.816 & 58.458 \\
\hline $\begin{array}{l}\text { Method (mechanical } \\
\text { prosthetic AVR) }\end{array}$ & 0.056 & 1.842 & 0.985 & 3.442 \\
\hline
\end{tabular}

Table IX. Evaluation of relationship between cover measurements and PLT measurements in biological AVR group $(n=97)$

\begin{tabular}{lcc} 
Parameter & \multicolumn{2}{c}{ Size } \\
Minimum PLT & 'r & 0.009 \\
\cline { 2 - 3 } & $p$ & 0.930 \\
\hline Time to reach the minimum [days] & $r$ & -0.016 \\
\cline { 2 - 3 } & $p$ & 0.880 \\
\hline Difference preop-min. PLT & $r$ & 0.012 \\
\cline { 2 - 3 } & $p$ & 0.908 \\
\hline
\end{tabular}

' $r$ - Pearson correlation coefficient, $r$-Spearman's correlation coefficient.

In a double-center study conducted by Repossini et al. on 254 patients, it was reported that thrombocytopenia developed after implantation of the Sorin Freedom Solo valve prosthesis. It was determined that thrombocytopenia improved over 10 to 15 days without specific treatment, which was considered to be a transient phenomenon. It has been stated in a study that there is a relationship between the prosthetic valve size and the decrease in platelet levels. It has been reported that the probability of postoperative thrombocytopenia is reduced in patients using larger valve prostheses [15]. This may be due to turbulence which is typically seen in all types of prosthetic valves and is more severe in the small size ring [16]. In their study using Perceval sutureless aortic valves, Mujtaba et al. found a significant decrease in platelet count, requiring platelet suspension and erythrocyte transfusion [17].

However, in our study, no statistically significant relationship was found between the valve measurements and the minimum PLT and time to minimum $(r=0.009 ; r=-0.016$; $p>0.05$ ). Here was no statistically significant relation between the measurements of the valve and the preop-minimum PLT differences $(r=0.012 ; p>0.05)$ (Table IX).

A study by Stanger et al. compared the thrombocytopenia observed after bioprosthetic valve operations in which stented, stentless, and sutureless bioprostheses were used. In this study, the use of Pericarbon Freedom, Perceval S and SOLO bioprosthetic valves showed a marked decrease in the postoperative platelet counts as compared to non-Sorin valves. However, the use of these valves has not been associated with bleeding complications, and they stated that this is a transient side effect on platelets [18]. In a study by Yerebakan et al. in which platelet counts after implantation 
of stentless (Sorin Freedom Solo) and stented (Sorin Mitroflow) bovine pericardial bioprostheses were compared, the mean platelet count in the Sorin Mitroflow group was moderately lower than the baseline values on the postoperative $3^{\text {rd }}$ day whereas the platelet loss was more pronounced in the Sorin Freedom Solo group. They also observed that the thrombocytopenia was recovered without causing any major problem. A study of the relationship between antiaggregant drug therapy and platelet count by Yerebakan et al. reported that while clopidogrel was added to the treatment on the $3^{\text {rd }}$ postoperative day, a serious decrease in platelet count had already been observed before clopidogrel treatment was started. In the same study, no correlation was observed between decreased platelet counts in patients receiving clopidogrel compared to other patients [19].

Another study, by Repossini et al., reported analysis of platelet activation with two different bioprostheses [Sorin Freedom Solo (FS) and Carpentier-Edwards Magna (CE)] after AVR. Postoperative changes in such parameters as platelet count, prothrombin, P-selectin, and $\beta$-TG were followed to test platelet activation and blood coagulation activation. They found that the platelet count was significantly reduced after Freedom Solo implantation compared to the other group. However, the factors involved in platelet activation and blood coagulation activation did not change significantly, indicating that the implanted bioprosthesis did not affect platelet and blood coagulation activation [20].

In a study that established the hypothesis that heparininduced thrombocytopenia (HIT) might be responsible for thrombocytopenia seen after Freedom Solo bioprosthesis implantation, HIT antibody was investigated in half of the patients. No HIT antibody was detected in any patient. Forty percent of these patients had been treated with danaparoid. However, alteration of anticoagulation therapy was found to have no effect on the platelet count [19]. The same study also referred to glutaraldehyde, a storage solution for the bioprosthesis valve, and suggested that the toxic effect of glutaraldehyde on thrombocytes on glutaraldehydefixed bioprosthetic valves could not be removed by rinsing.

The results of our study strongly suggest that postoperative thrombocytopenia in the three groups of patients we examined is a transient phenomenon that spontaneously recovers within one week without any intervention and in which no recurrence is observed in late follow-up (including routine post-discharge visits). In our study, thrombocytopenia was observed in $96.9 \%$ of patients with bioprosthetic AVR. This rate was $72 \%$ in patients with mechanical prosthetic AVR (Table I). The incidence of thrombocytopenia in the bioprosthetic AVR group was significantly higher than in the mechanical prosthetic AVR $(p=0.001)$ and CABG ( $p$ $=0.001)$ groups $(p<0.01)$ (Table IV). Severe thrombocytopenia $\left(0-50\left(1000 / \mathrm{mm}^{3}\right)\right)$ was observed in $21.6 \%$ of patients with bioprosthetic AVR. Patients who underwent mechanical prosthetic AVR and CABG did not have severe thrombocytopenia. In patients with bioprosthetic AVR, the lowest platelet levels were observed on the postoperative second day. In terms of differences between the preoperative and the lowest postoperative platelet measurements, the values of the bioprosthetic AVR group were significantly higher than the mechanical prosthetic AVR $(p=0.001)$ and CABG $(p=0.001)$ groups $(p<0.01)$ (Table IV). There was no statistically significant difference between platelet levels according to bioprosthetic valve sizes $(p>0.05)$ (Table VI). We investigated the relationship between the bleeding complications requiring postoperative intervention and the postoperative platelet count. There was no statistically significant relationship between the presence of a bleeding complication requiring postoperative intervention and the postoperative lowest platelet counts $(p>0.05)$. Causes of the number of patients undergoing reoperation due to bleeding being higher in the CABG group were thought to be specific to coronary artery bypass surgery, not related to thrombocytopenia. There was no statistically significant correlation between the presence of a bleeding complication requiring postoperative intervention and postoperative thrombocytopenia $(p>0.05)$ (Table III).

Other studies in this regard and our study show that thrombocytopenia is frequently observed after cardiac surgery employing CPB. In patients with bioprosthetic AVR, an increase in both the frequency and severity of postoperative thrombocytopenia was observed. This condition improved in about one week and the platelet count returned to preoperative values. The relationship between thrombocytopenia and a bleeding complication requiring postoperative intervention was not significant $(p>0.05)$.

The study we conducted was retrospective and singlecentered, and the desired variety was not achieved in prosthetic valve types used in operations. An investigation of the coagulation system has not been done in these patients. Again, immunohistochemical and tissue analyses of the used prosthetic valves were not performed. A multicenter and detailed study of a larger patient population will provide more guidance in this regard.

\section{Conclusions}

As seen in our study, postoperative thrombocytopenia is a reality in patients undergoing bioprosthetic AVR. Thrombocytopenia after bioprosthetic AVR is considered to be a complex and multifactorial phenomenon, and more comprehensive and detailed studies are needed on the factors at play. In accordance with the literature, our study showed that thrombocytopenia following bioprosthetic AVR done with the same surgical techniques and principles recovers without causing any problem. It is postulated that the shear forces may cause washout of chemicals responsible for thrombocytopenia from the glutaraldehyde-treated bioprostheses.

Studies conducted up to this point suggest that suspicion of glutaraldehyde treatment during the construction of bioprosthetic valves is the cause of thrombocytopenia observed after bioprosthetic heart valve replacement. Although thrombocytopenia does not appear to have any effect on postoperative complications, caution should be exercised in the use of drugs affecting platelet number and 
function in these patients and precautions against bleeding problems should be taken.

\section{Disclosure}

The authors report no conflict of interest.

\section{References}

1. Greisshammer M, Bangerter M, Sauer T, Wennauer R, Bergmann L, Heimpel H. Etiology and clinical significance of thrombocytosis: analysis of 732 patients with an elevated platelet count. J Intern Med 1999; 245: 295-300.

2. Martin JF, Daniel TD, Towbridge EA. Acute and chronic changes in platelet volume and count after cardiopulmonary bypass induced thrombocytopenia in man. Thromb Haemost 1987; 57: 55-58.

3. Warkentin TE, Greinacher A. Heparin-induced thrombocytopenia and cardiac surgery. Ann Thorac Surg 2003; 76: 2121-2131.

4. Matthai WH Jr, Cines DB. Towards a diagnosis of heparin-induced thrombocytopenia after cardiopulmonary bypass. J Thromb Haemost 2004; 2: 18791881.

5. Gresele P, Fuster V, Lopez JA, Page CP, Vermylen J. Platelets in Hematologic and Cardiovascular Disorders: A Clinical Handbook. Cambridge University Press 2017.

6. Bojar RM. Manual of Perioperative Care in Adult Cardiac Surgery. John Wiley \& Sons 2011; 281-312.

7. Hammermeister KE, Sethi GK, Henderson WG, Oprian C, Kim T, Rahimtoola S; Veterans Affairs Cooperative Study on Valvular Heart Disease. A comparison of outcomes in men 11 years after heart-valve replacement with a mechanical valve or bioprosthesis. N Engl J Med 1993; 328: 1289-1296.

8. Jamieson WR, Burr LH, Miyagishima RT, Germann E, Anderson WN. Actuarial versus actual freedom from structural valve deterioration with the Carpentier-Edwards porcine bioprostheses. Can J Cardiol 1999; 15: 973-978.

9. Burr LH, Jamieson WR, Munro Al, Miyagishima RT, Janusz MT, Ling H, Hayden RI, Tutassaura H, Fradet G, Gudas VM, et al. Structural valve deterioration in elderly patient populations with the Carpentier-Edwards standard and supra-annular porcine bioprostheses: a comparative study. J Heart Valve Dis 1992; 1: 87-91.
10. Jamieson WR, Burr LH, Munro Al, Miyagishima RT. Carpentier-Edwards standard porcine bioprosthesis: a 21-year experience. Ann Thorac Surg 1998; 66: 40-43.

11. Wang HL, Aguilera C, Knopf KB, Chen TB, Maslove DM, Kuschner WG. Thrombocytopenia in the intensive care unit. J Intensive Care Med 2013; 28: 268280.

12. Matthai WH. Thrombocytopenia in cardiovascular patients: diagnosis and management. Chest 2005; 127: 46-52.

13. Hilker L, Wodny M, Ginesta M, Wollert HG, Eckel L. Differences in the recovery of platelet counts after biological aortic valve replacement. Interact CardioVasc Thorac Surg 2009; 8: 70-73.

14. Ravenni G, Celiento M, Ferrari G, Milano A, Scioti G, Pratali S, Bortolotti U. Reduction in platelet count after aortic valve replacement: comparison of three bioprostheses. J Heart Valve Dis 2012; 21: 655-661.

15. Repossini A, Bloch D, Muneretto C, Piccoli P, Bisleri G, Beholz S. Platelet reduction after stentless pericardial aortic valve replacement. Interact Cardiovasc Thorac Surg 2012; 14: 434-439.

16. O'Brien MF. The Cryolife-O'Brien. Composite aortic stentless xenograft: surgical technique of implantation. Ann Thorac Surg 1995; 60: S410-S413.

17. Mujtaba SS, Ledingham S, Shah AR, Schueler S, Clark S, Pillay T. Thrombocytopenia after aortic valve replacement: comparison between sutureless perceval S Valve and Perimount Magna Ease Bioprosthesis. Braz J Cardiovasc Surg 2018; 33: 169-175.

18. Stanger O, Grabherr M, Gahl B, Longnus S, Meinitzer A, Fiedler M, Tevaearai H, Carrel T. Thrombocytopaenia after aortic valve replacement with stented, stentless and sutureless bioprostheses. Eur J Cardiothorac Surg 2017; 51: 340-346.

19. Yerebakan C, Kaminski A, Westphal B, Kundt G, Ugurlucan M, Steinhoff G, Liebold A. Thrombocytopenia after aortic valve replacement with the Freedom Solo stentless bioprosthesis. Interact Cardiovasc Thorac Surg 2008; 7: 616-620.

20. Repossini A, Tononi L, Martinil G, Di Bacco L, Girolettiz L, Rosati F, Muneretto C. Platelet activation after sorin freedom solo valve implantation: a comparative study with Carpentier-Edwards Perimount Magna. J Heart Valve Dis 2014; 23: 777-782. 